\title{
Structural Interpretation and Attribute Evaluation for Characterization of Oil Field: A Case Study of "Sowari" Field, Niger Delta, Nigeria
}

\author{
Osaki Lawson-Jack $^{1 *}$, Itiowe Kiamuke ${ }^{2} \&$ Mgbeojedo Tochukwu Innocent ${ }^{3}$ \\ ${ }^{I *}$ Department of Physical and Chemical Sciences, Elizade University, Ilara Mokin, Ondo state, Nigeria. ${ }^{2}$ Department of Earth \\ Sciences, Arthur Jarvis University, Akpabuyo, Cross River State. ${ }^{3}$ Geotechnical Department, Arab Center for Engineering Studies, \\ Doha, Qatar. "Email: osaki.lawson-jack@elizadeuniversity.edu.ng
}

Copyright: (12021 Osaki Lawson-Jack et al. This is an open access article distributed under the terms of the Creative Commons Attribution License, which permits unrestricted use, distribution, and reproduction in any medium, provided the original author and source are credited.

\section{ABSTRACT}

Effective structural interpretation and attribute analysis using well logs, high-resolution 3D seismic data and surface attributes maps of the Sowari field Niger Delta, Nigeria have been successfully investigated. The approach includes correlation of wells using GR and SP logs to establish the lithology of the Formation, identification of reservoirs from the resistivity logs, horizon and fault mapping, generation of depth structure map and surface attribute analysis. Two horizons, H1 and H2 were mapped, and structure contour maps produced for each of the horizons. The study of faults showed a complex pattern of subsurface structures. The formation has extensive simple rollover structures bounded by growth faults trending in the NNW direction. Faulted rollover anticlines exist in the middle zone while the southern area is featured by collapsed crest structures. Structural closures considered as good hydrocarbon prospects were identified and delineated. Horizon (H1) lies at a depth of $2758 \mathrm{~m}$, and Horizon (H2) is at a depth 3190m across the reservoir. Average energy, Maximum Amplitude and RMS Amplitude surface attribute maps were extracted to reveal bright spot and high amplitude zones. Thus, seismic attribute analysis is a good complement to conventional structural interpretation, identification and correlation of geological structures.

Keywords: Seismic interpretation, Seismic attributes, Niger delta, Faults, Amplitude.

\section{Introduction}

Challenges posed by reservoir heterogeneities have resulted in some wells with poor economics. Seismic interpretation approach has been the common method of interpreting seismic data for the overall purpose of mapping geological structures, subsurface stratigraphy and reservoir geometry. The spatial expression of seismic reflectors is qualitatively mapped over time with little or no emphasis on the inherent variations in the seismic amplitude [4], but then, the addition of the 3D seismic revolution makes use of amplitudes to be vital part of seismic interpretation and allowed the discernment of more valuable geological information from the evaluation of seismic attributes. Seismic attributes are different techniques to observe the original seismic data, which is usually displayed in amplitudes, and good in identifying packages of amplitudes which represents mainly the acoustic impedance contrast, hence reflectivity. In seismic interpretation process, the use of seismic attributes allows a significant improvement in the signal-to-noise ratio, the enhancement of seismic reflectors continuity, the automatic detection of discontinuities, predicting facies distribution in study areas and the enhancement of direct hydrocarbon indicators. Truly, seismic attributes provide a better correlation between the data provided by the seismic reflection method, well log data and the geology of the study area.

Textural and surface seismic attributes are usually associated with chaotic reflections on seismic sections with low energy and low trace-to-trace similarity. Since the first publications on this technology [13], many other successful applications of these attributes reveal vertical hydrocarbon migration pathways, bright spots, salt diapers, sand bodies, channels, fault seal analysis and prospect ranking have been reported around the world $[1,5,12,13]$. Although major studies by $[2,3,6-9,15,18]$ have been done in Niger Delta basin to examine the influence of 


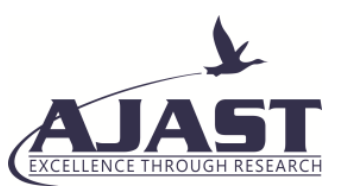

Asian Journal of Applied Science and Technology (AJAST)

Volume 5, Issue 1, Pages 121-130, January-March 2021

structural evolution on sand depositional pattern, their distribution and thickness have not been fully explored using the combined benefit of amplitude seismic modeling attributes, which emphasizes the inherent seismic amplitude variations. A joint effort of average energy, maximum amplitude and RMS amplitude attribute is a powerful exploration tool to delineate trapping mechanisms and hydrocarbon movements between chimneys and faults with a view to reducing exploration risk in reservoirs and seals as shown in Table 1.

Seismic profiles define the subsurface geometry and make fair computation of the acoustic impedance - formation densities and velocities thus providing nearly its continuous lateral view. The prime object of seismic interpretation is to prepare contour seismic maps showing the two-way travel time to a reflector as picked from seismic events. Horizon and fault picking is carried out after well to seismic tie was done. Time and depth structure maps were displayed to reveal the structural geometry and stratigraphic variation, which can better reveal and confirm features by the integration of average energy, maximum amplitude and RMS amplitude attribute studies. Therefore, seismic amplitude attributes significantly increased the signal-to-noise ratio, resolved areas with low resolution, detected subtle lithological variations, enhanced seismic reflectors continuity, helped in structural interpretation, and enhanced depositional features that can help to better understand the geology of a study area.

Table 1. Geological significance of seismic attributes (source: Schlumberger, 2009)

\begin{tabular}{|c|c|}
\hline Seismic attribute & Geological significance \\
\hline Amplitude & $\begin{array}{c}\text { Lithological contrast } \\
\text { Bedding continuity } \\
\text { Bed spacing } \\
\text { Gross porosity Fluid content }\end{array}$ \\
\hline $\begin{array}{l}\text { Instantaneous } \\
\text { frequency }\end{array}$ & $\begin{array}{l}\text { Bed thickness } \\
\text { Lithological contrast Fluid content }\end{array}$ \\
\hline Reflection strength & $\begin{array}{c}\text { Lithological contrast } \\
\text { Bedding continuity } \\
\text { Bed spacing Gross porosity }\end{array}$ \\
\hline Instantaneous phase & Bedding continuity \\
\hline Polarity & $\begin{array}{l}\text { Polarity of seismic } \\
\text { Lithological contrast }\end{array}$ \\
\hline
\end{tabular}

Because the main objective of this study is to provide a synergistic approach towards understanding and validation of seismic interpretation approach, therefore, surface attributes maps (Average energy, maximum amplitude and RMS amplitude attribute) were generated from the interpreted horizons of the seismic interpretation techniques 


\section{A TAST}

Asian Journal of Applied Science and Technology (AJAST)

Volume 5, Issue 1, Pages 121-130, January-March 2021

using well log data and 3D seismic section of the Sowari field Niger Delta, Nigeria. Integration of seismic interpretation method and surface attribute analysis is cost effective, robust and model independent, where spatial correlation to porosity and reservoir delineation are sharper and better defined for qualitative interpretation and further seismic analysis.

\subsection{Geology of the study area}

Bida field is situated on Latitude $3^{\circ}$ and $6^{\circ} \mathrm{N}$ and Longitudes $5^{\circ}$ and $8^{\circ} \mathrm{E}$, Niger Delta Nigeria (Fig.1). The field is part of the general sequence of the Agbada Formation and structure. It consists of a simple rollover anticline bounded to the north by a significant growth fault. This sedimentary basin is a clastic environment dominated by sands and shales. The Niger Delta province contains a single identified hydrocarbon system [18] called Tertiary Niger Delta (Akata-Agbada) Hydrocarbon System. The area is geologically a sedimentary basin and consists of three Formations: Akata, Agbada and Benin Formations. The Akata is made of thick shale sequences and serves as a potential source of rock.

It is assumed that it was formed as a result of the transport of clays in deep waters at the beginning of the Paleocene. According to [6] the thickness of this Formation is estimated at around 7,100 meters thick, and it is under the whole delta with a high overpressure. Agbada Formation is the main delta oil and gas reservoir. This is the transition zone and consists of the interbedding of sandstone and shale (more than 3800 meters thick) and represents the delta part of the Niger Delta. Agbada Formation is overlain by the top Formation, which is Benin. Benin Formation is made of sands of about $2000 \mathrm{~m}$ thick [11].

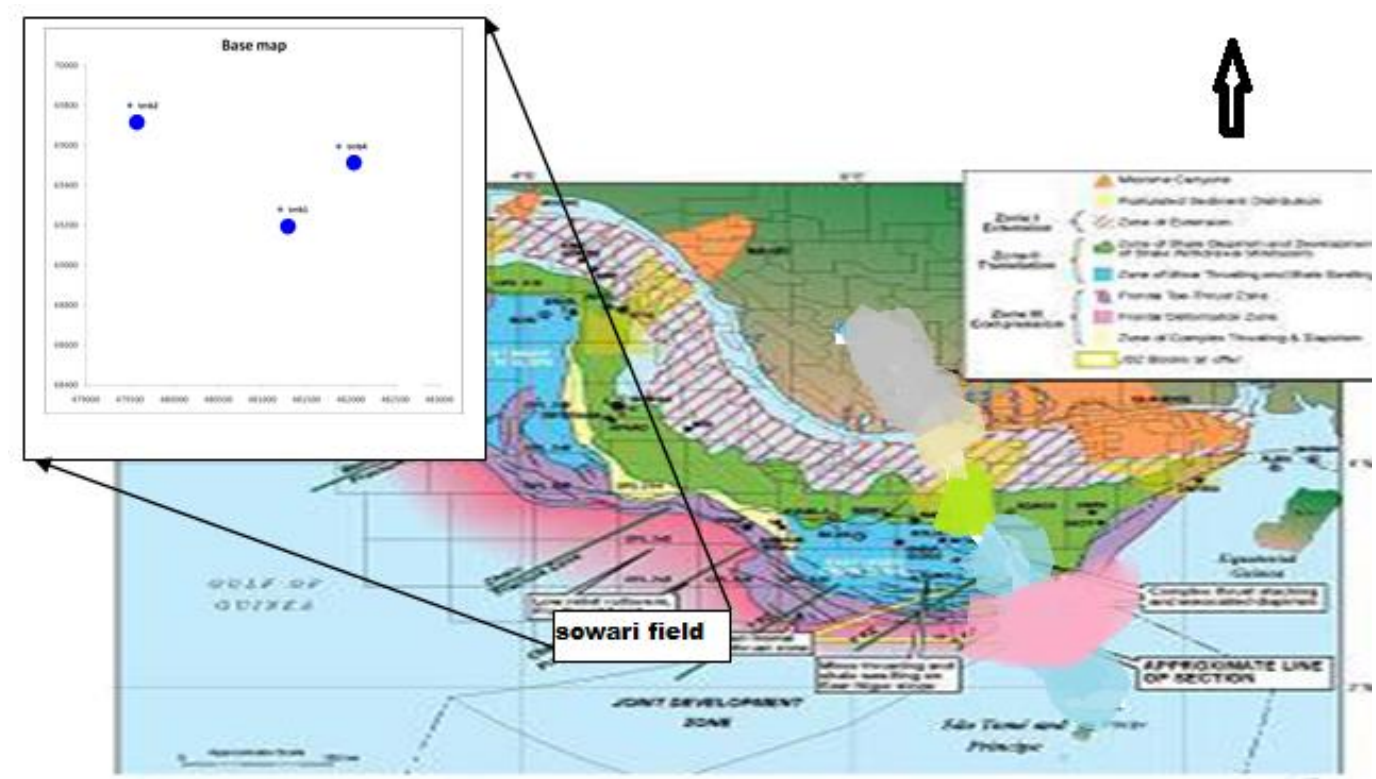

Fig.1. Map of Niger Delta basin showing location and base map (well points in blue dots) of Sowari field

\section{Materials and Methodology}

The following was gathered for interpretation: well logs, seismic sections of the field, a base map, check-shot data and Petrel software. The study is subdivided into two major sections, seismic interpretation and seismic attribute analysis section. The former includes loading collected data into Petrel software, quality checking of data, 


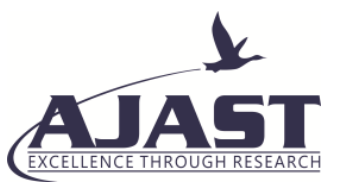

Asian Journal of Applied Science and Technology (AJAST)

Volume 5, Issue 1, Pages 121-130, January-March 2021

correlation of wells (SO-100, SO-200, SO-300), plotting a good well to seismic tie for better time to depth domain match, picking of faults $\left(\mathrm{F}_{1}, \mathrm{~F} 2, \mathrm{~F} 3, \mathrm{~F} 4\right)$ and horizons $(\mathrm{H} 1$ and $\mathrm{H} 2)$ on seismic section and generation of time and depth structure maps of the field, while the latter includes the extraction of seismic attribute (Average energy, maximum amplitude and RMS amplitude attribute) maps from the horizons (H1 and H2) to confirm and enhance the geologic geometry that was evaluated using seismic interpretation approach. It can also depict anomalies generated from the seismic interpretation.

\section{Results and Discussion}

Detailed results obtained from the study are presented in this section and as follows:

\subsection{Structural Interpretation of the seismic data}

The horizons mapping was carried out first, by the delineation of three wells named SO-100, SO-200, SO-300 in a well correlation panel. Two horizons $\mathrm{H}_{1}$ and $\mathrm{H}_{2}$ were identified using gamma ray and SP logs. Resistivity, sonic, neutron and density logs were further used to identify pore fluid types of the wells, hence confirming the area of interest. The first surface (H1) lies at a depth of $2758 \mathrm{~m}$, and the second surface (H2) is at a depth of $3190 \mathrm{~m}$ across the reservoir. The lithological and stratigraphic study of the Formation using GR logs show that the geological units are mainly sand and shale, with an increasing trend of high sand/ shale ratio, confirming that the area of interest lies within the Agbada Formation of the Niger Delta [15] as shown in Fig.2. Well to seismic tie which superimposes the depth domain in the logs with the time domain in the 3D seismic section was good and effective. The Formation reveals four major faults (F1, F2, F3, F4) and the horizon (H1 and H2) as shown on inline 5890 in Fig.3 and the fault interpretations revealed F1 and F3 as listric faults, which are the major structure building faults representing the growth faults in the area, while fault F2 and F4 are antithetic faults.

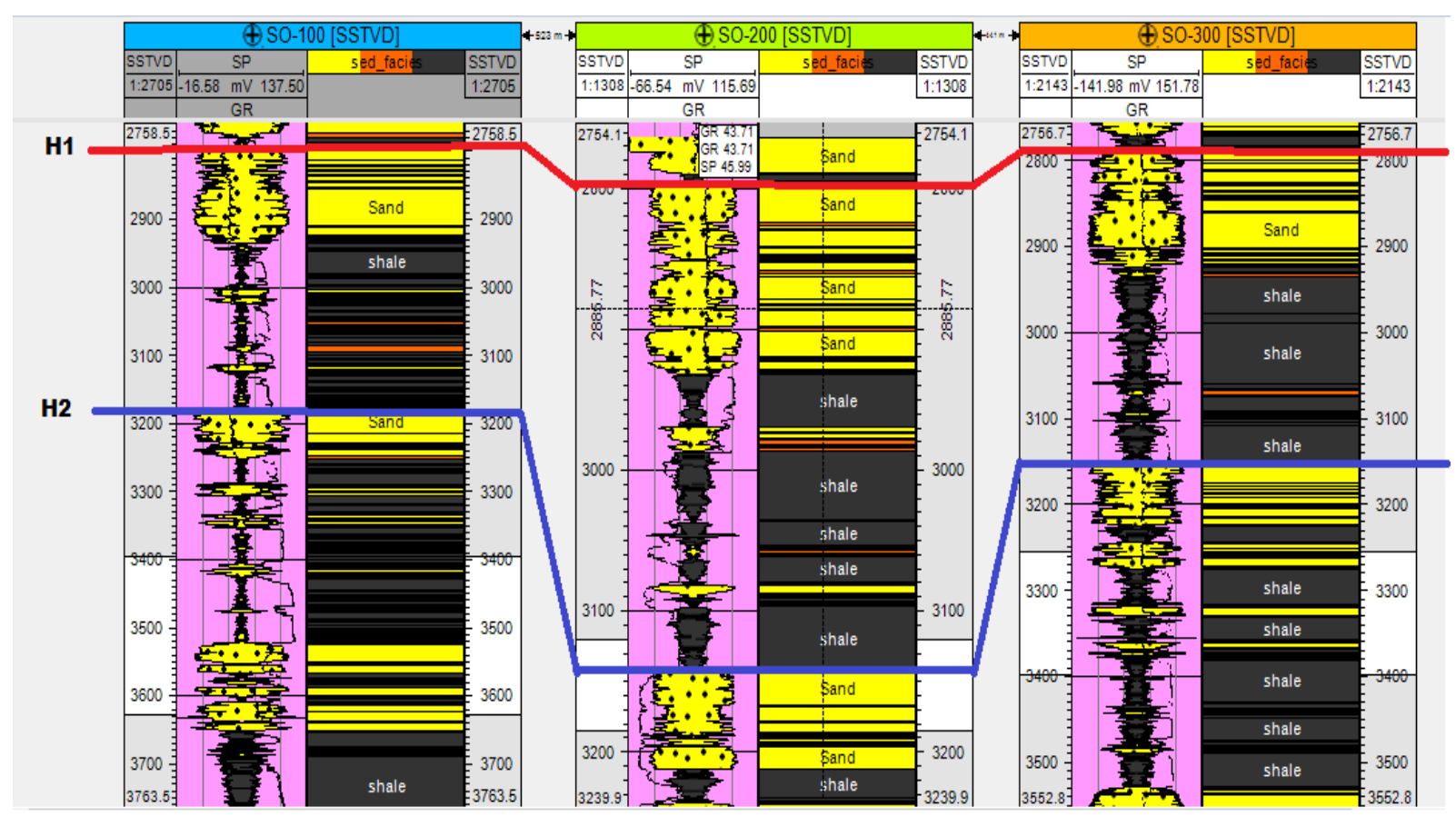

Fig.2. Well log correlation panel of SO-100, SO-200 and S0-300 showing geological units which are predominantly sand and shale with the delineated horizons (H1 and H2) using GR and SP logs 


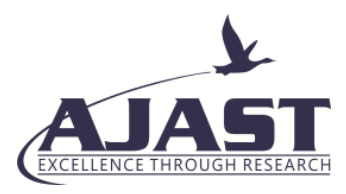

Asian Journal of Applied Science and Technology (AJAST)

Volume 5, Issue 1, Pages 121-130, January-March 2021

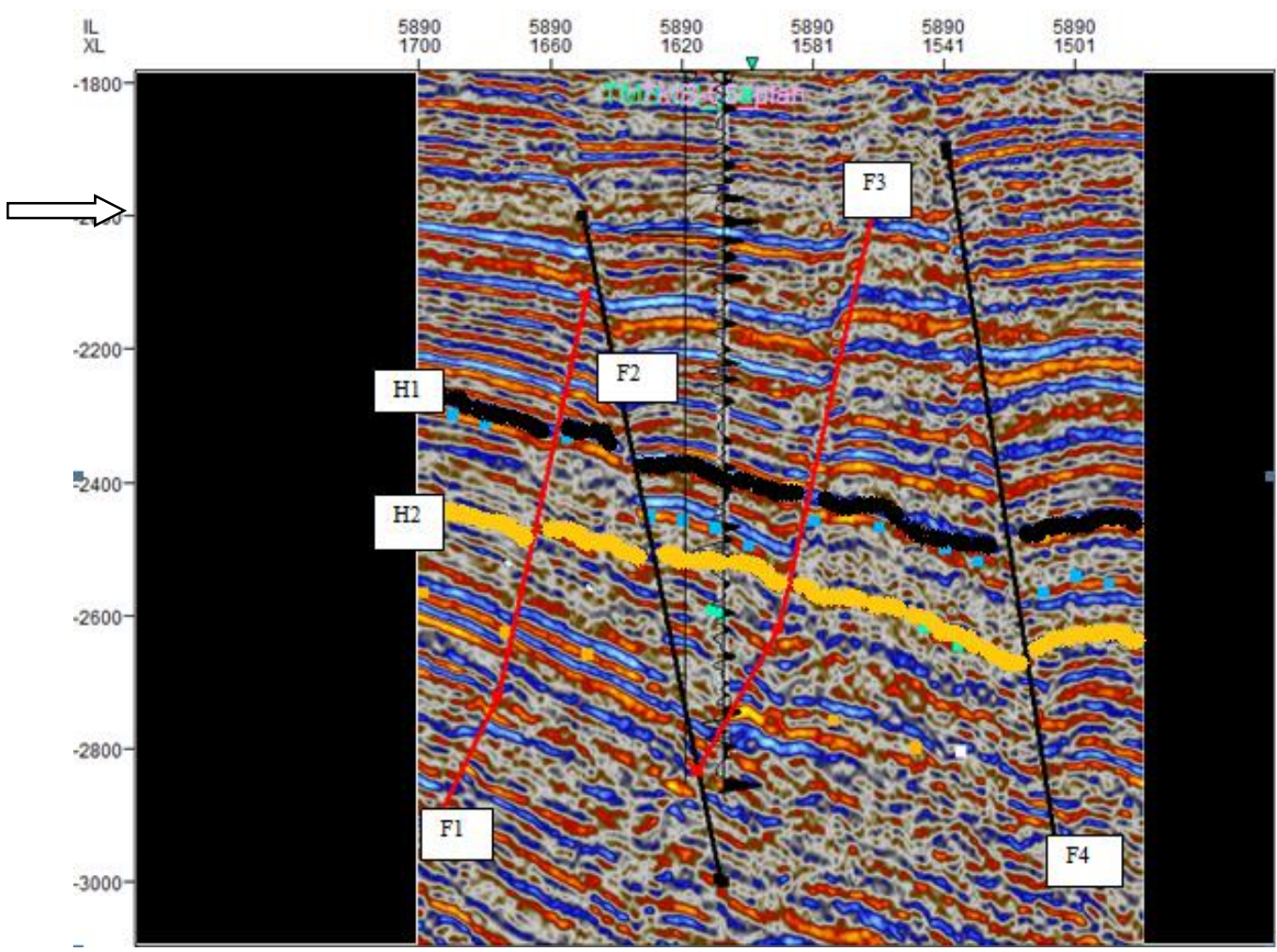

Fig.3. Seismic section of inline 5890 showing the fault geometry and identified horizons (H1 \& H2)

\subsection{Time and Depth structure map of Surfaces}

Fig. 4, 5, 6 and 7 show the time and depth structure maps of $\mathrm{H} 1$ and $\mathrm{H} 2$. The depth maps were extracted by the conversion of the time maps. As a result of the nearness of the horizons, the structural style is similar; the entire structural trapping mechanism consists of an anticline (structural highs) at the NW zone and two-way rollover structure assisted by faults (F2 \& F3). This appears to be the principal structure responsible for hydrocarbon entrapment in this hydrocarbon field and it trends in the NNE direction.

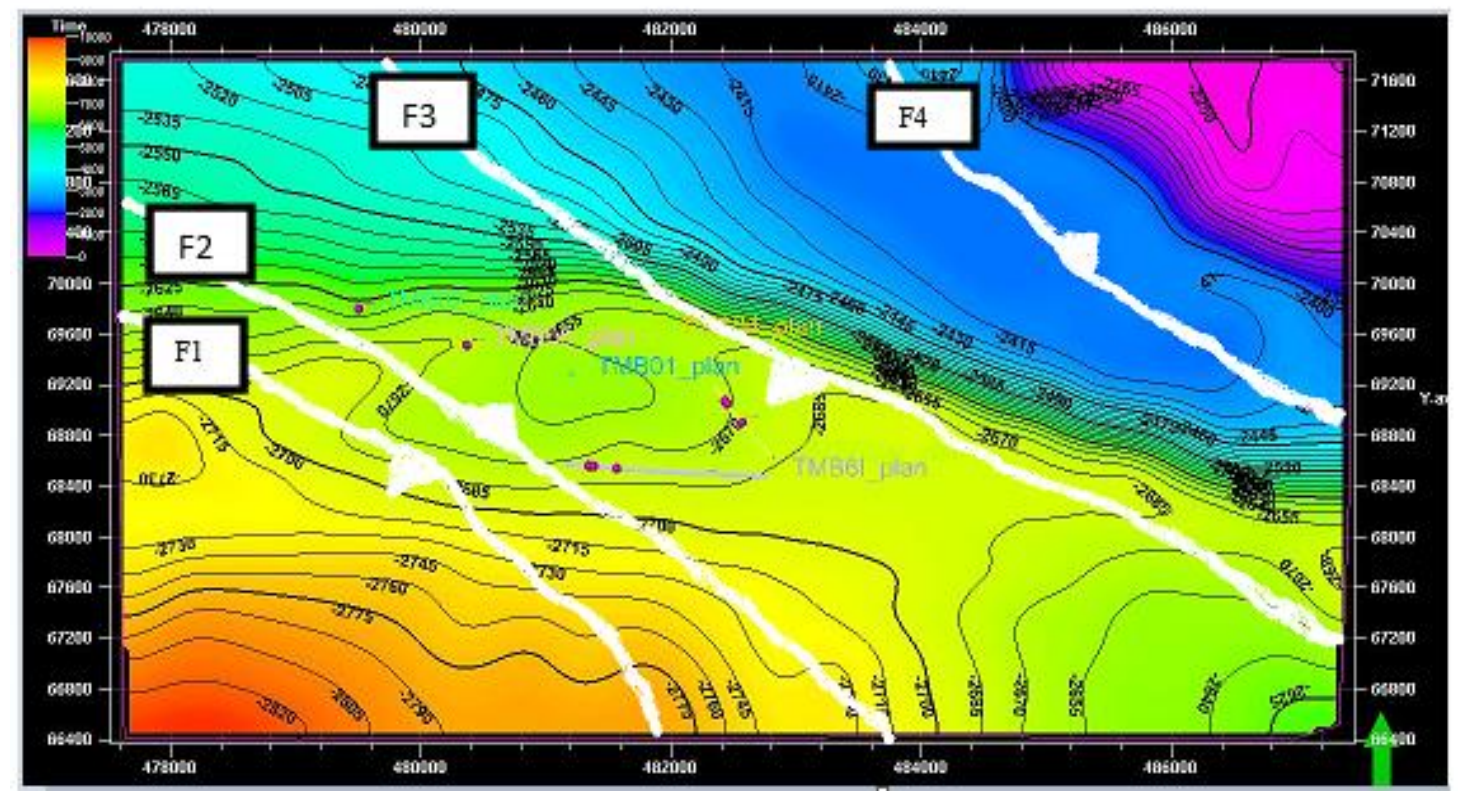

Fig.4. Time structure map of horizon (H1) showing faults patterns 


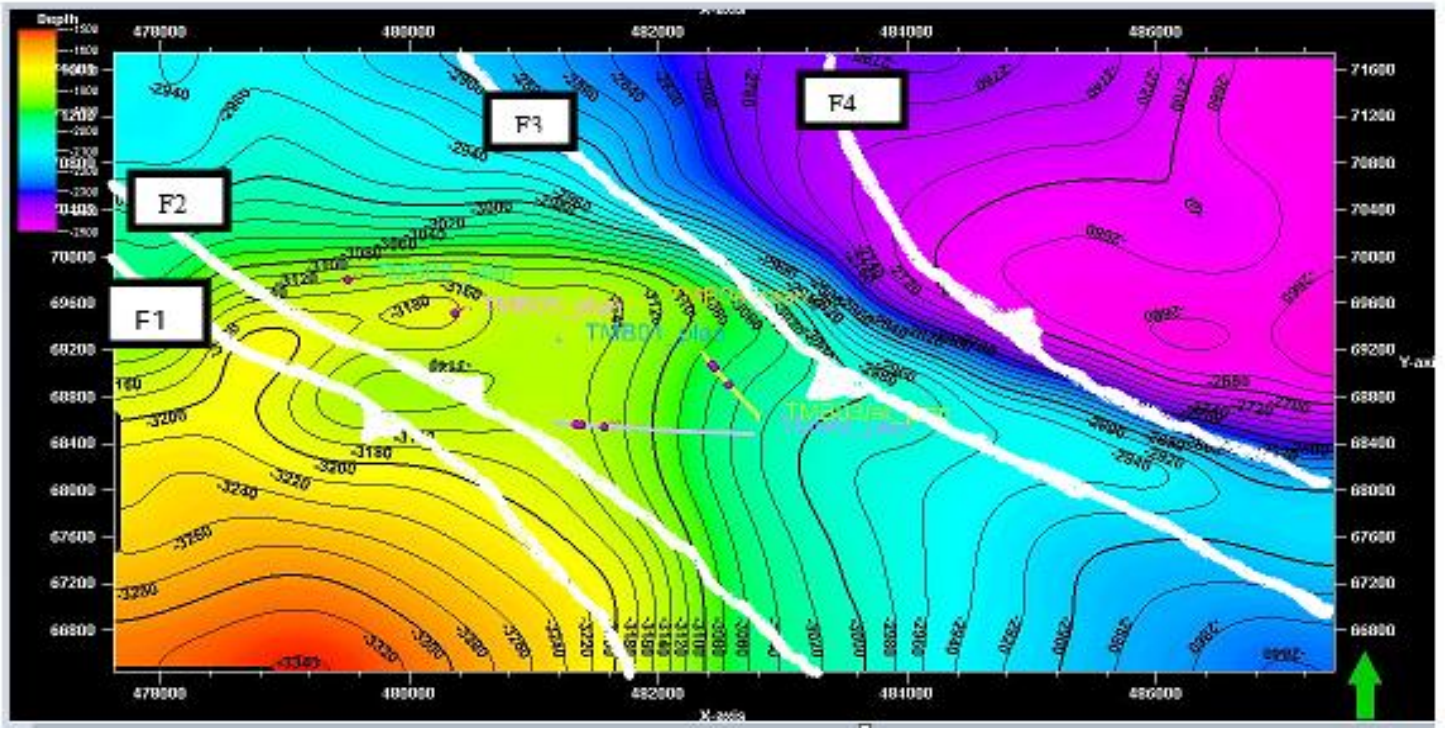

Fig.5. Time structure map of horizon (H2) showing faults patterns

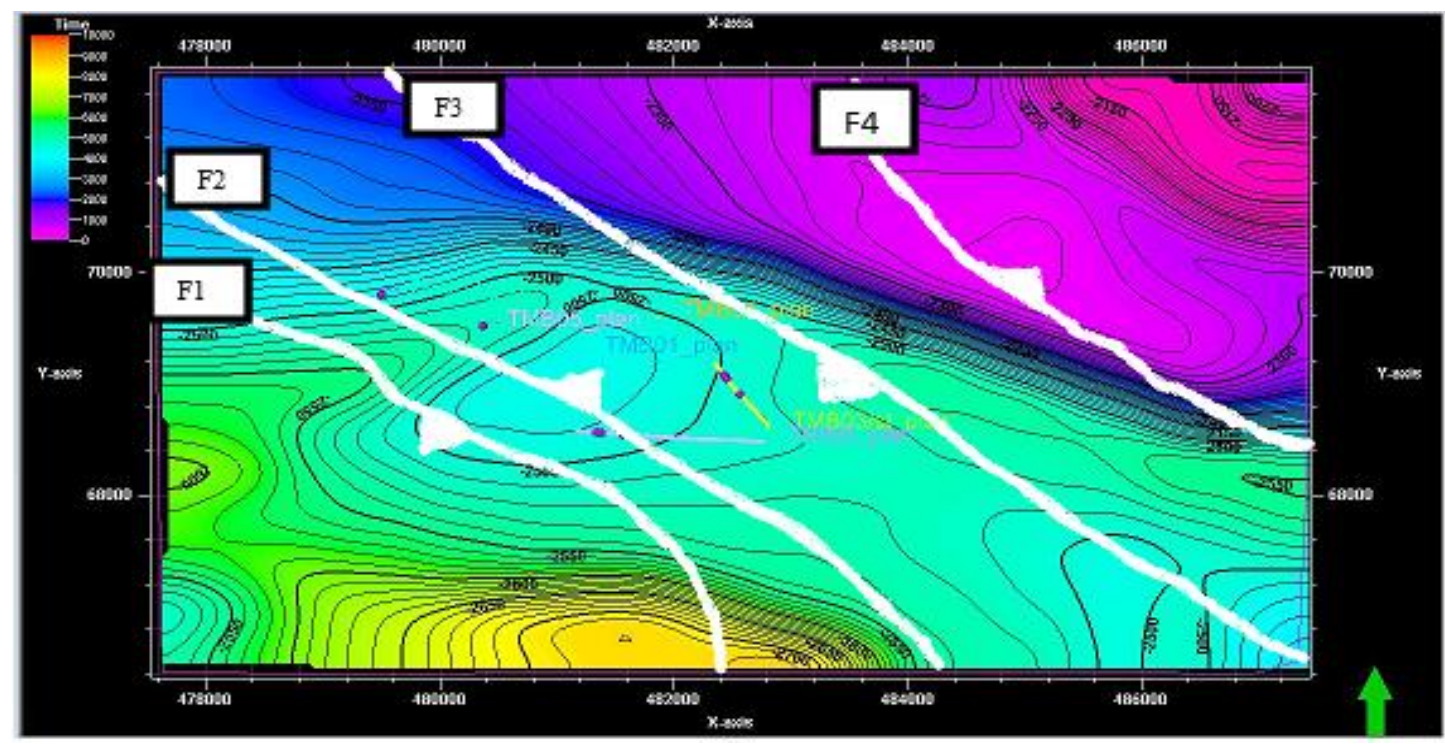

Fig.6. Depth structure map of horizon (H1) showing major faults and anticlinal structure of the Sowari field

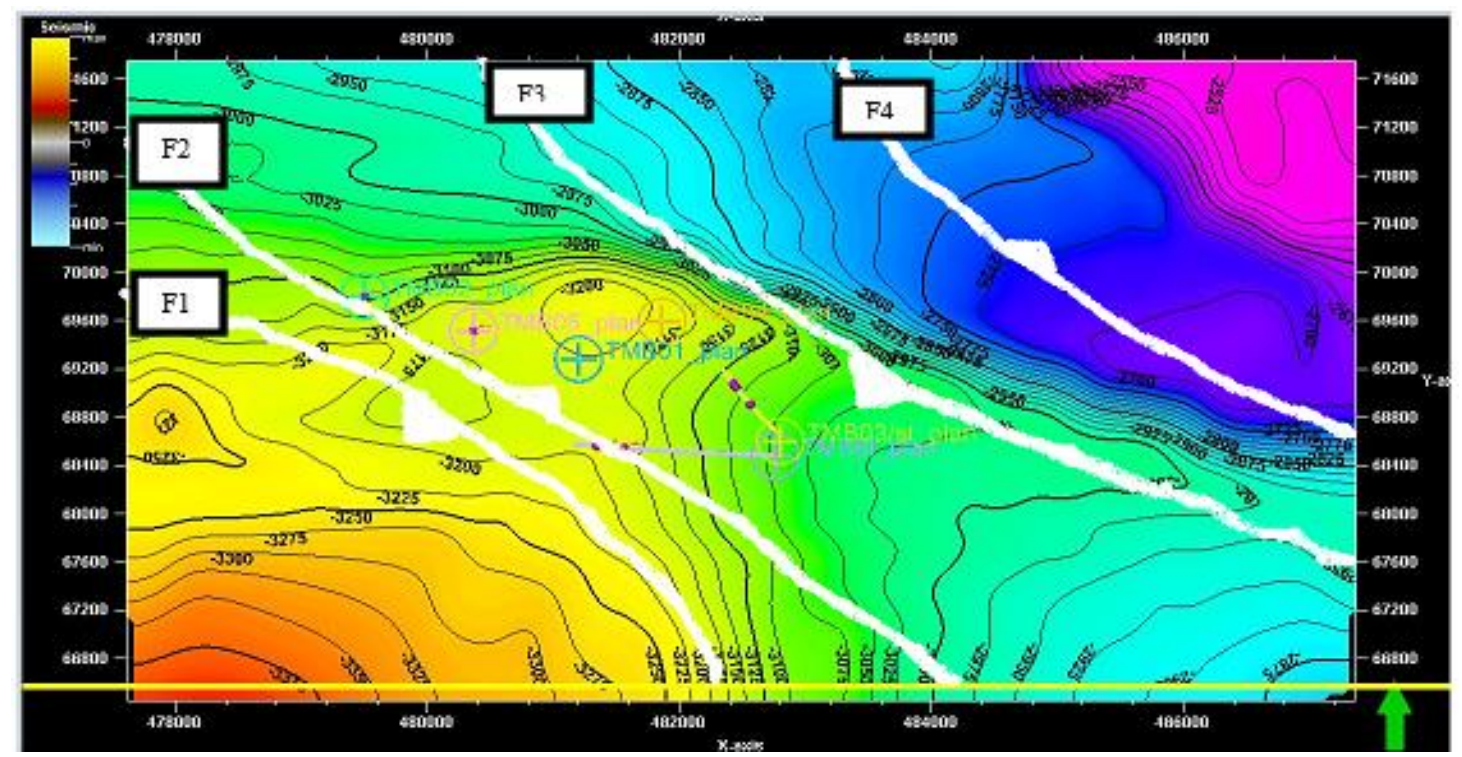

Fig.7. Depth structure map of horizon (H2) showing major faults and anticlinal structure of the Sowari field 


\section{AJAST}

Asian Journal of Applied Science and Technology (AJAST)

Volume 5, Issue 1, Pages 121-130, January-March 2021

\subsection{Seismic Attribute Interpretation}

Average energy, maximum amplitude and RMS amplitude attribute maps where extracted from the surfaces representing $\mathrm{H} 1$ and $\mathrm{H} 2$ as shown in Figs. 8, 9 and 10. High amplitude areas were seen around the NNE zone and it shows consistency and similarity on all seismic attribute maps generated.

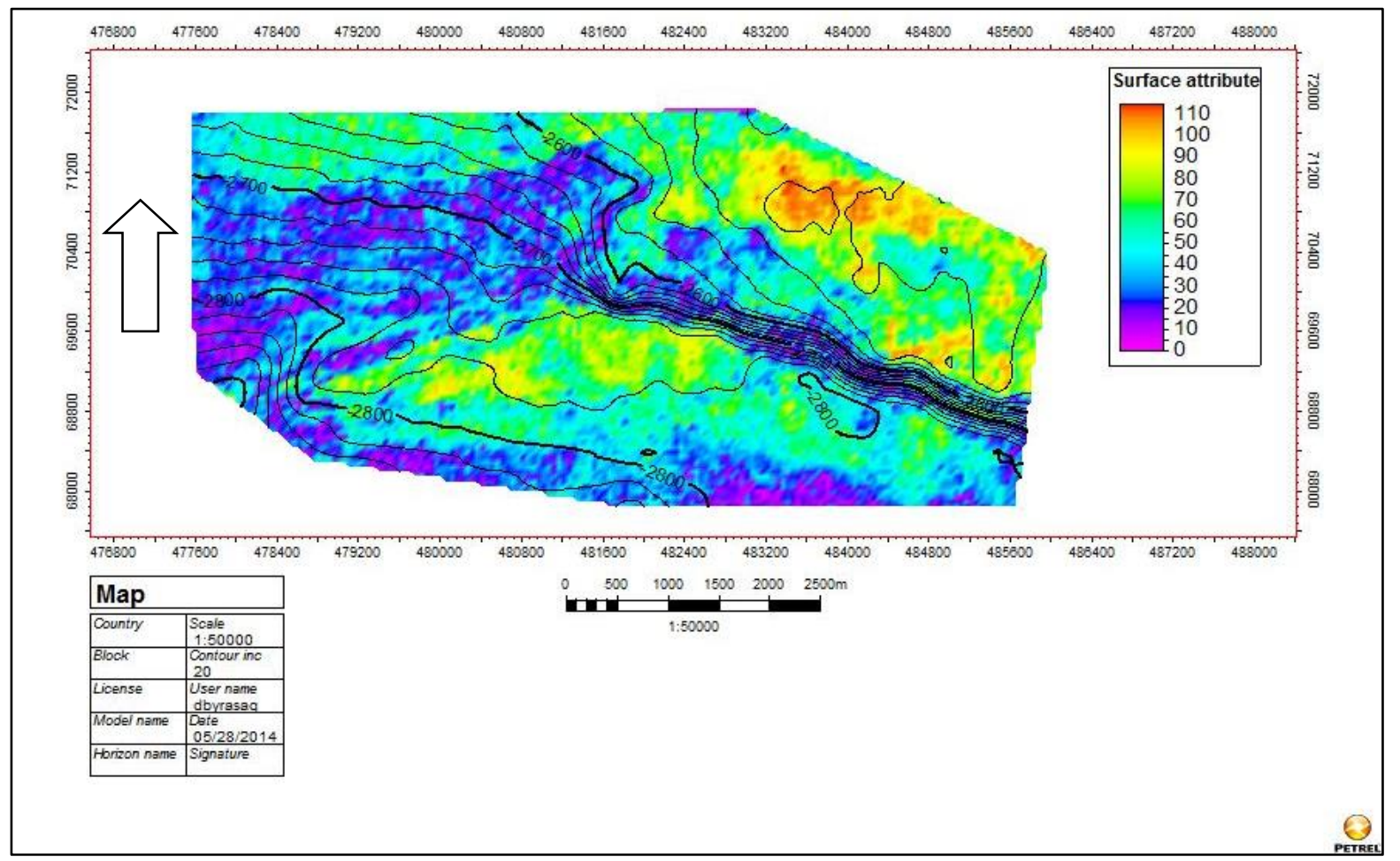

Fig.8. RMS attribute map of horizon (H1)

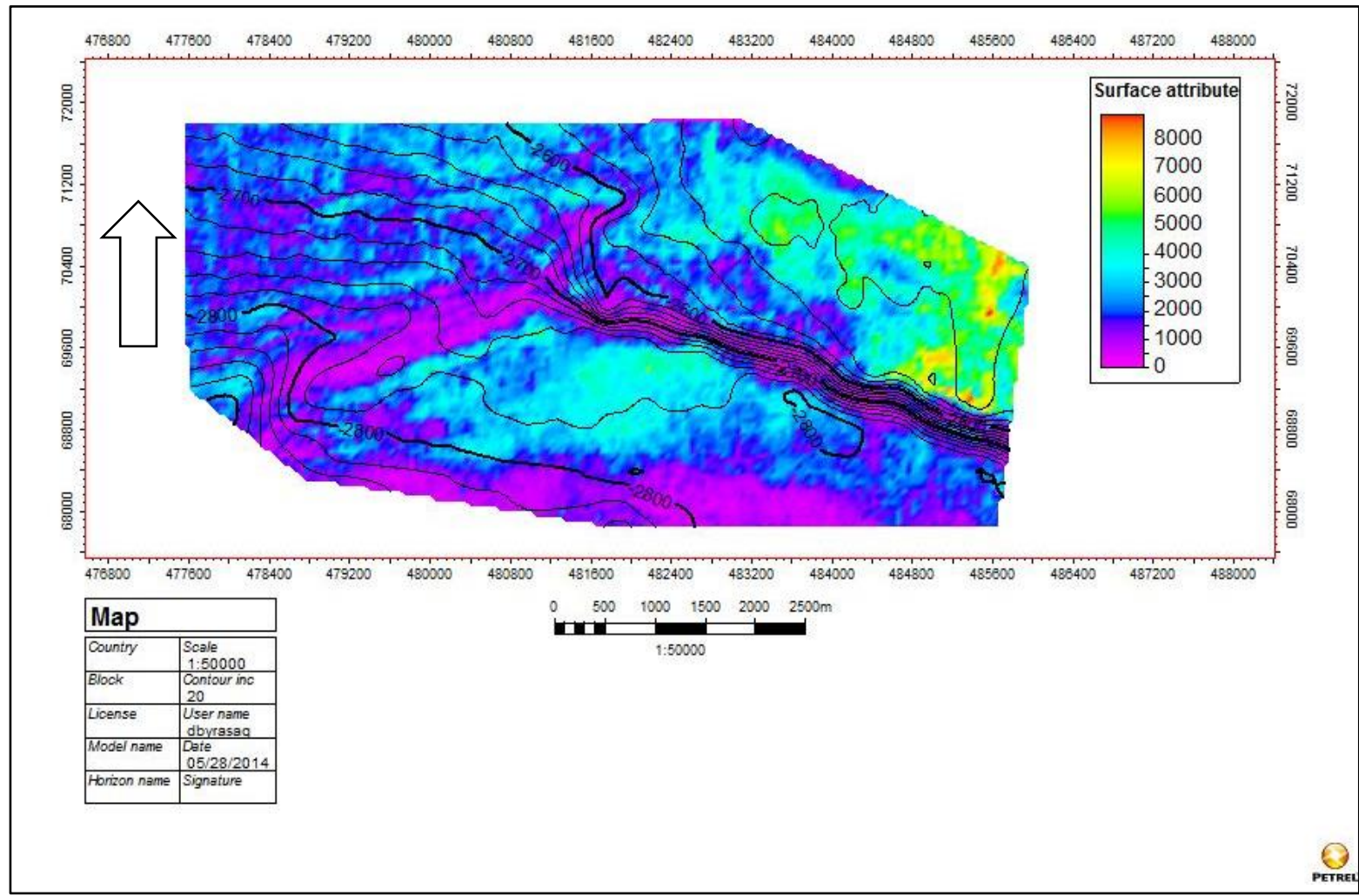

Fig.9. Maximum amplitude attribute map of horizon (H1) 


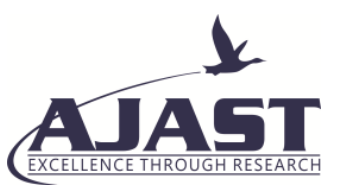

Asian Journal of Applied Science and Technology (AJAST)

Volume 5, Issue 1, Pages 121-130, January-March 2021

The high amplitude area (orange and yellow) as seen in the RMS attribute map (Fig.8) may be hydrocarbon saturated sand zones overlying shale (green and blue) as a result of acoustic impedance contrast of the fluid or lateral change in lithology. Figure 9 depicts the maximum amplitude attribute map with bright spots also at the NNE zone of the map which is due to the spatial variation in porosity of the lithofacie. While the yellow and green zone represents a more porous unit, the blue to dark blue represents a less porous formation. The average energy map of the horizons also shows similarity in the lateral distribution of rock properties and fluid type as shown in Fig.10. Bright zones are direct hydrocarbon indicator (DHI) as seen at the NNE area of the map. This prospect zone with orange colour is likely fluid filled with gas saturation, because increase in gas saturation tends to decrease density and compression velocity of a reservoir rock.

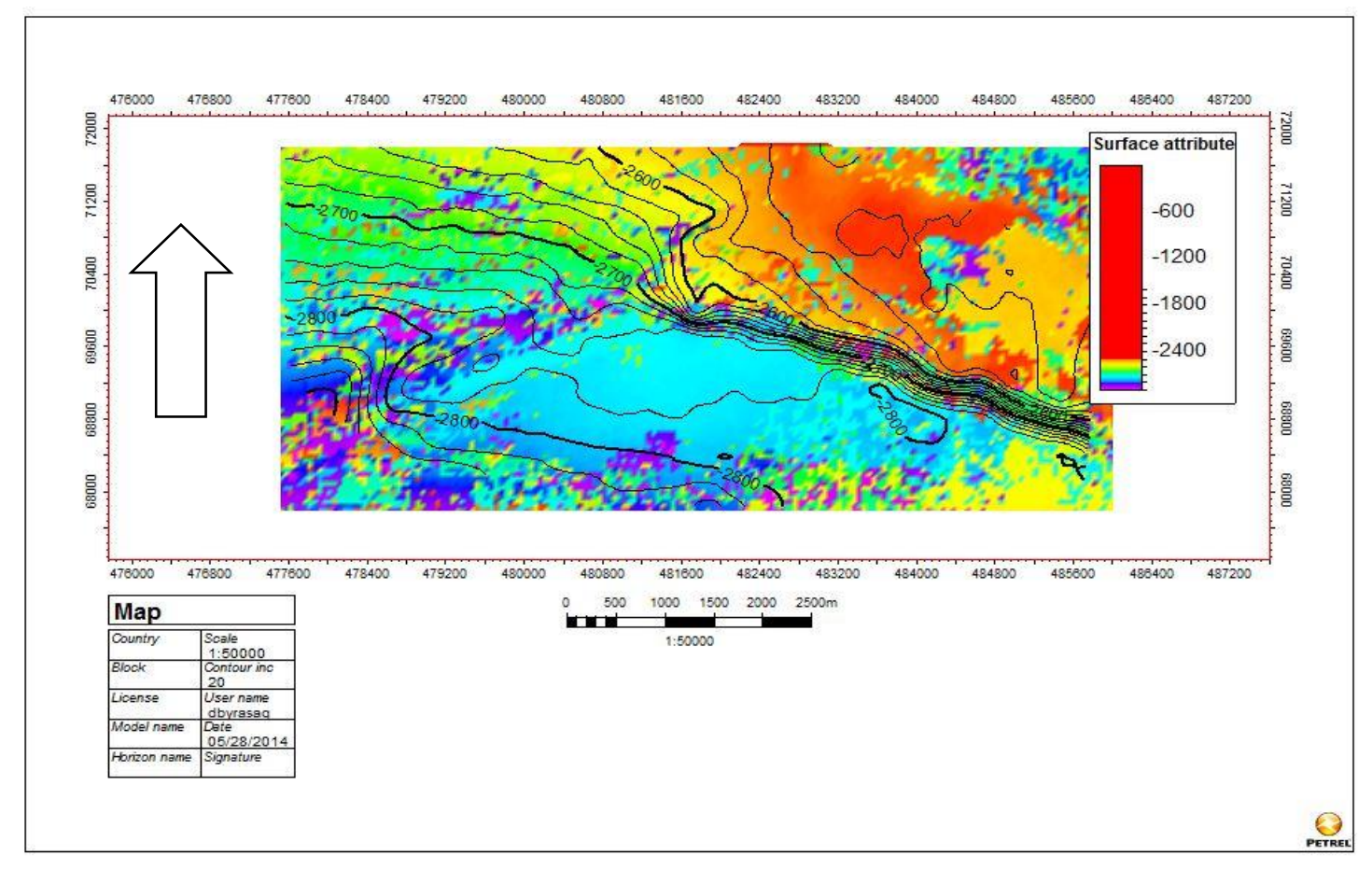

Fig.10. Average energy map of horizon (H1)

\section{Conclusion}

The applications of seismic attributes provide a new idea for deciphering fine and complicated structures, and significantly contribute to the development of objective and precise geological interpretation. The structural disposition and the lateral lithofacie distribution of the Sowari oil field were adequately evaluated and analyzed with seismic interpretation and seismic attribute approach using 3D seismic volume and well log data of the studied field. The study revealed two major lithogical units in the area to be sand and shale.

A critical examination of the various maps shows the presence of structures (growth fault and anticline) that can possibly reserve hydrocarbon in the study area. An anticlinal structure was observed at the NNW portion of the study area dipping NNE direction and closing on the major faults F2 and F3. This shows that the trapping mechanism is a fault-assisted anticlinal structure. The major faults polygons around the closures serve as seals which can help to trap hydrocarbons migrating to the surface as a result of gravitational push. The four major faults tagged F1, F2, F3, and F4 were generated across the field. 


\section{AJAST}

Asian Journal of Applied Science and Technology (AJAST)

Volume 5, Issue 1, Pages 121-130, January-March 2021

Average energy, maximum amplitude and RMS amplitude attribute maps reveals possible hydrocarbon prospect zone at the NNE zone of the studied surface, bright spot and high amplitude at the NNE area shows porous formation with variation in fluid contact overlying a non-porous formation. It also explains displacement of fluid from the high structure zone with F1 and F2 to the NNE zone (bright spot on attribute map). In this research work, it was found that multi-attribute analysis is a very useful means of highlighting an interested geobody. It has been further demonstrated that seismic attributes are complementary to the facts derived through traditional approach of seismic interpretation. Extraction of seismic attributes from seismic data can bring innovative information and insights into stratigraphic and hydrocarbon accumulation potential in reservoir area. The deliverables from seismic attributes extraction and analysis will help greatly in understanding broader basin wide correlation of lithofacies and controls of depositional environment.

\section{Acknowledgements}

The authors of this paper are grateful to the management of Elizade University, ilara Mokin, Ondo State for logistic support during this research work.

\section{Declarations}

\section{Source of Funding}

This research did not receive any specific grant from funding agencies in the public, commercial, or not-for-profit sectors.

\section{Competing Interests Statement}

The authors declare no competing financial, professional and personal interests.

\section{Consent for publication}

We declare that we consented for the publication of this research work.

\section{Code availability}

The programming code that we have used for this research is available and authors are willing to share when it is required.

\section{References}

1. Aminzade, F., and D. Connolly, 2002, Looking for gas chimneys and faults: AAPG Explorer, 23, 20-21.

2. Beka, F.T., Oti, M.N.: The distal offshore Niger Delta: frontier prospects of a mature petroleum province, In: Oti, M.N., and Postma, G., eds., Geology of Deltas. Rotterdam, A.A. Balkema, 237-241 (1995).

3. Bustin, R.M.: Sedimentology and characteristics of dispersed organic matter in Tertiary Niger Delta: origin of source rocks in a deltaic environment. American Association of Petroleum Geologists Bulletin 72, 277-298 (1988) https://doi.org/10.1306/703C8C18-1707-11D7-8645000102C1865D.

4. Chopra, S., Marfurt, K.J., 2005. Seismic attributes --- A historical perspective. Geophysics 70, 5, pp. 3SO-28SO 
Asian Journal of Applied Science and Technology (AJAST)

Volume 5, Issue 1, Pages 121-130, January-March 2021

5. Connolly, D., F. Aminzade, P. de Groot, J. H. Litenberg, and R. Sawyer, 2002, Gas chimney processing as a new exploration tool: A West African example: Proceeding of AAPG Annual Meeting, 10-13.

6. Doust, H. and Omatsola, E. (1990) Niger-Delta. In: Edwards, J.D. and Santogrossi, P.A., Eds., Divergent/Passive Margin Basins, AAPG Memoir 48, American Association of Petroleum Geologists, Tulsa, 239-248.

7. Ejedawe, J.E., Coker, S.J.L., Lambert-Aikhionbare, D.O., Alofe, K.B., Adoh, F.O. : Evolution of oil-generative window and oil and gas occurrence in Tertiary Niger Delta Basin, American Association of Petroleum Geologists 68, 1744-1751 (1984) https://doi.org/10.1306/AD46198F-16F7-11D7-8645000102C1865D.

8. Ejedawe, J.E.: Patterns of incidence of oil reserves in Niger Delta Basin. American Association of Petroleum Geologists 65, 1574-1585 (1981) https://doi.org/10.1306/03B59620-16D1-11D7-8645000102C1865D.

9. Ekweozor, C.M., Daukoru, E.M.: Northern delta depobelt portion of the Akata-Agbada petroleum system, Niger Delta, Nigeria, In: Magoon, L.B., and Dow, W.G., eds., The Petroleum System--From Source to Trap, AAPG Memoir 60: Tulsa, American Association of Petroleum Geologists 599-614 (1994).

10. Heggland, R., P. Meldahl, B. Brill, and P. de Groot, 1999, The chimney cube, an example of semiautomated detection of seismic objects by directive attributes and neural networks: Part 2. Interpretation: 69th Annual International Meeting, SEG, Expanded Abstracts, 935-940, http://dx.doi.org/10.1190/1.1821263.

11. Kulke, H.: Nigeria, In: Kulke, H., ed., Regional Petroleum Geology of the World. Part II: Africa, America, Australia and Antarctica. Berlin, Gebrüder Borntraeger 143-172 (1995).

12. Litenberg, J. H., and R. O. Thomsen, 2003, Fluid migration path detection and its applications for fault.

13. Meldahl, P., R. Heggland, B. Brill, and P. de Groot, 1999, The chimney cube, an example of semiautomated detection of seismic objects by directive attributes and neural networks: Part 1. Methodology: 69th Annual International Meeting, SEG, Expanded Abstracts, 931-934.

14. Meldahl, P., R. Heggland, B. Brill, and P. de Groot, 2001, Identifying faults and gas chimneys. multi-attributes and neural networks: The leading edge, 20, 474-482.

15. Opara, A.I., Anyiam, U.O., Nduka, A.V. : 3-D Seismic Interpretation and Structural Analysis of Ossu Oil Field, Northern Depobelt, Onshore Niger Delta, Nigeria. The Pacific Journal of Science and Technology 12(1), 502-509 (2011).

16. Reijers, T.J.A., Petters, S.W., Nwajide, C.S. : The Niger Delta Basin, In : Selley, R.C., ed., African Basins--Sedimentary Basin of the World 3, Elsevier Science Amsterdam, the Netherlands, 151-172 (1997).

17. Schlumberger. Geological significance of seismic attribute. 2009 http:// www.glossary.oilfield.slb.com.

18. Weber, K.J., Daukoru, E.M.: Petroleum geology of the Niger Delta. Proceedings of the Ninth World Petroleum Congress, volume 2, Geology: London, Applied Science Publishers, Ltd., 210-221 (1975).

19. Xiao, H., Suppe, J.: Origin of rollover. American Association of Petroleum Geologists Bulletin 76, 509-229. (1992) https://doi.org/10.1306/BDFF8858-1718-11D7-8645000102C1865D. 